\title{
Improving the lack of missional effectiveness of congregations with small satellite meetings from an interdisciplinary practical theological perspective
}

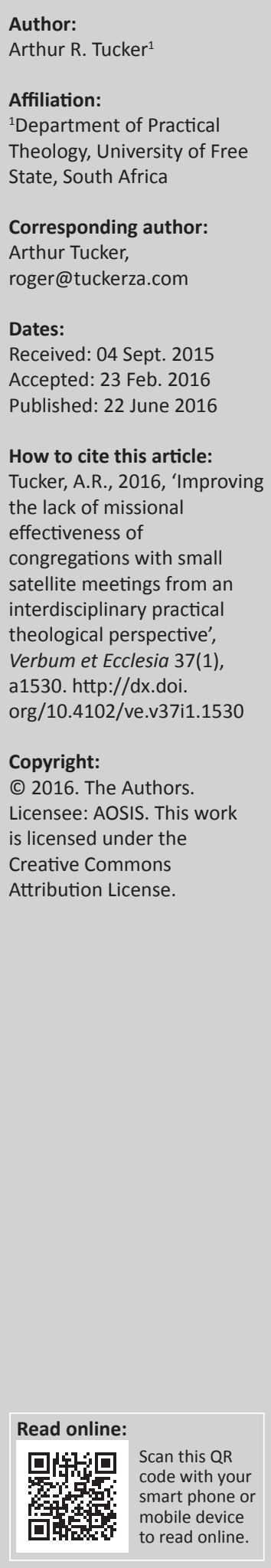

\begin{abstract}
There is much literature concerning small church groups. We are swamped with articles and blogs about what to do to make your small group succeed. Many of these are purely pragmatic, with a smattering of theology or ecclesiology. I believe it is time to take a fresh practical theological look at their place in congregational life and their ecclesiological role. One aim of the missional concept is that congregations transform the communities in the contemporary worlds in which they exist. Whilst many churches now have a dual structure of small satellite groups attached around the main larger worship meeting variously known as cell groups, life groups, etc., it would appear from research that they are not using this dual combination effectively from a missional perspective and thus are not being as effective as they could be in fulfilling the missio Dei. This article attempts to learn how this may be improved using an interdisciplinary practical theology approach combining what may be learnt about this dual structure from the sociology of groups, church history, ecclesiology, and contemporary contextual studies. It concludes by making appropriate recommendations.

Intradisciplinary and/or interdisciplinary implications: This article suggests how their effectiveness may be significantly improved using an intra/interdisciplinary practical theology approach combining what may be learnt about this dual structure from the sociology of groups, church history, perception theory in the area of ecclesial paradigms, missional and Trinitarian ecclesiology, and contemporary contextual studies. It concludes by making appropriate recommendations.
\end{abstract}

\section{Introduction}

In the first section of this study I answer the question, 'why revisit such a well-worn subject as the dual structure' in church praxis? I suggest three reasons: dual structures are not being as missionally effective as they might be in today's church; they were used, seemingly very effectively in the early church; and ignorance of developments in contemporary ecclesiology relating to the use of small satellite groups connected to a 'whole' church meeting.

Before I begin, it is necessary to make it clear that this study rejects three misconceptions. The first is that there is a normative ecclesiological model to be discovered in the New Testament. The second is that any New Testament pattern of ecclesiological structure can be applied in unmodified form to the contemporary world. The third is that the application of ecclesiological principles found in the New Testament to the contemporary church will necessarily, of itself, result in church growth. As Calvin (1970) writes:

As for the external disciplines and the ceremonies, he (God) has not chosen to prescribe for us in particular, and as it were, word for word, how we must be governed... one and the same form would be neither appropriate nor useful for all ages. (pp. 10,30)

\section{Reasons for revisiting the dual group structure concept Its lack of missional ineffectiveness in today's world}

Many have questioned the effectiveness of small groups in missional proclamation. Indeed as far back as Wuthnow's (1994) groundbreaking study concerning small groups in the United States he sounds a note of warning quoting Olson's 1989 research. Olson (1989:432) conducted a study of 762 attenders at five Baptist churches in suburban Minneapolis. The surprising conclusion he arrived at

Note: This article is partially based on the author's dissertation of the degree of Doctor of Theology at the Faculty of Theology, University of Pretoria, South Africa, with supervisor Prof. Dr C.J.A. Vos and co-supervisor Prof. Dr M. Nel, received May 2003, available here: http:// www.sats.edu.za/userfiles/SATS $\% 20$ compilation $\% 20$ of $\% 20$ thesis.pdf? 
was that those congregations with the highest number of church friends per member 'showed attendance decline or stasis'. Wuthnow (1994:332) then comments in connection with the friendships that small groups encourage that, 'these same friendships may also hinder recruitment of newcomers'. They are not often open communities that welcome and reach out to strangers. They may simply provide occasions for individuals to focus on themselves rather than on others (Wuthnow 1994:6).

Walker (2014:106) believes that this is a relevant finding even 20 years later, having no problem with applying it to his recent research into 'Fresh Expressions' in the United Kingdom. 'A closed society no longer has any future. It kills the hope for life of those who stand on the periphery and then finally destroys itself' (Moltmann 1978:35). If a group does not have mission as a goal it can easily become selfcentred and cliquish.

In fact this seemed to be confirmed by my doctoral research (Nel, Tucker \& Smit 2004) into 30 churches with small groups in the Cape Province. This appeared to show that, whilst small groups were very effective in instruction and care, there was no statistically significant difference in the recruitment of newcomers through 'professed conversion' between churches that had small groups and those that did not.

An examination of the contemporary Internet will also reveal the vast number of articles about how to make small groups connected to 'whole' church meetings actually reach the unchurched and introduce such newcomers into the congregations they are connected to. It would be fair to assume that this huge amount of 'how to' literature would be unnecessary if the introduction of newcomers through small groups was a normal happening! To draw an analogy, a plethora of laws are often only enacted when they are failing to address the problem, as was the case with the oft-enacted ineffective sumptuary ${ }^{1}$ (permitted dress and clothing) laws in Medieval Europe.

\section{The missional fruitfulness associated with a dual structure in the early church}

'Western churches experienced a major reduction in membership during the 20th century' (Dreyer 2012:1). Yet, most scholars would agree that, in contrast, the early church experienced phenomenal growth (Bird 2002:227) during the first century $\mathrm{AD}$ and for at least the first four centuries thereafter (Dreyer 2012:1). In fact, Finn (2000:295ff.) estimates that there was a $40 \%$ growth rate until $350 \mathrm{AD}$, which resulted in an increase from 1000 Christians in $40 \mathrm{AD}$ to nearly 34 million during this time period. Whilst many factors contributed to that rapid growth, it is suggested that the dual structure combining 'the intimacy of warm relationships with the clarity of organizational structures' (Dudley \& Hilgert 1987:2, 23) may have been one factor.

So if such a structure was very effective missionally then, why not now? I believe that there are many reasons, but will mention 1.Laws restricting what clothes the various levels of society might wear. the three most important. These involve congregational culture (or 'church paradigm'), an appropriate context, and ignorance about how to use it most effectively in modern cultures which are often characterised by individualism, as opposed to those communal cultures of the ancient world. (This latter comment would of course apply to cultures in South Africa of European origin and not to indigenous cultures, which are influenced by the Ubuntu community ethic).

\section{Support from contemporary developments in theology and ecclesiology}

The first ecclesiological development that had a direct influence on the dual structure concept arose in Germany. In 1669, Spener, a Lutheran minister, had come to see that the church's identity required Christians to meet together regularly in small groups to encourage and discipline one another (Young 1989:107). To Spener this was not, 'a pastoral strategy but a necessary correlate of ecclesiology' (Hadaway, DuBose \& Wright 1987:49). Thus in 1675 Spener wrote Pia Desideria, (Holy or Pious Desires), in which he developed his 'ecclesiolae in ecclesia', ecclesiology, translated as 'little church within the church' (Hadaway et al. 1987:49). By this he meant that the small group is as much a church as the main large group to which they were attached although it is subordinate to it and serves its aims.

The second development was the emergence of the Body of Christ metaphor in ecclesiology in the works of Bonhoeffer, then in Protestantism in general, which finally impacted Vatican II (Dulles 1987:51). The metaphor emphasises the importance of organisational structure and authority within the Body (see for instance Corinthians 11:17-22; 14:26-33, 40); the importance of intimate and warm relationships within the Body; that however small a group is, it is the church (the body of Christ); unity within diversity (Clowney 1988:531); the priesthood, and gifting by God, of all believers (Ephesians 4:9-16); and thus the mobilisation of all believers for service, especially for building each other up (Dulles 1987:53; O'Brien 1987:113; Van der Ven 1996:276) and in missional proclamation (Barth 1956:665; Welker 1994:310). Thus, it theologically reinforces the ecclesiolae in ecclesia concept and gives it ecclesiological respectability and depth. It also provides some idea of the communicative actions that one should expect to see in both small and 'whole church' large groups instruction (teaching and training and modelling), caring and pastoral nurturing, celebration (worship and fellowship), service of the Body and of the world, and proclamation (evangelism and preaching).

The third development has come through the Trinitarian 'explosion' in theology. This further underpinned a justification for the ecclesiolae in ecclesia concept, particularly that which rooted the identity of the church in the relationships of the Trinity in the economy of salvation known as social Trinitarianism (Volf \& Welker 2006:6). The church's identity is now anchored not only in revealed biblical metaphors such as the Body of Christ but in our understanding of the revelation of the economic Trinity. Thus diversity within unity becomes an attribute of the 
church's identity. This has structural implications because as Volf $(1998: 129,137)$ comments on Matthew 18:19-20 that the 'two or three' (which equals a small group) are as equally the 'church' as any larger gathering, because they are gathering to participate in the communion of the triune God.

In addition relational Trinitarian theology gives us a vision of God as a dynamic community of mutuality, openness, difference, and love that makes space for others to participate. These qualities define the image of God in which we are created (Van Gelder \& Zscheile 2011:108). Such a missional engendering relationality between members of the Body Christ can only really become a reality in a congregation with small groups in certain societal contexts. In these contexts the small group provides the opportunity for intimacy and informality whereas the 'whole' church meeting provides the necessary sense of purpose and cohesion to make the relationality work.

Such a theological basis reveals that in certain societal contexts the total relationality that reflects the image of the Triune God will often only be achieved through the a combination of the different dynamics provided within the small and 'whole' church group meeting structure. Moreover, for it to really work, congregations need to rediscover their identity in the Trinity as relational beings in the image of God. Thus in the same way, as for becoming a missional church, the dual structure will only be effective when the congregation is acting out of a relational church paradigm, that encourages diversity unified within a cohesive structure, rather than an institutional one.

\section{The evidence for the 'ecclesiolae in ecclesia', structure in the New Testament documents}

\section{The existence of small and large meetings}

The first part of the research, in this section, answers the question, 'Is there really a dual, "small and large" meeting structure that can be seen in the New Testament documents?'

The first piece of evidence is the practical consideration concerning the small size of many dwellings. The majority of urban inhabitants dwelt, 'in small dark, poorly ventilated, crowded buildings where privacy was unavailable' (Osiek \& Balch 1997:32). Archaeological evidence has led to estimates that the majority of private dwellings of even the middleclass wealthy were no larger than $100 \mathrm{~m}^{2}$ in houses in both Palestinian and Roman-Greek society (Dunn 1998:542). A house belonging to such a person would not have been able to accommodate more than 50 people without undignified overcrowding. Thus it seems likely that in many cities and towns the Christian community was composed of a number of small group subunits meeting in the much smaller houses of the less wealthy (Murphy-O'Conner 2004:42) which seem to have been a maximum size of $40 \mathrm{~m}^{2}$. Then that most meetings for the whole church would have had to be held in the more spacious homes of the wealthy, in one or two rooms of an insula (block of flats), in a large ground floor room in such a block (Osiek \& Balch 1997:33, 34), or in public buildings such as the temple etc. Thus it is not surprising that Acts records meetings in small private homes, upper rooms (presumably in apartment blocks), and less frequently in larger buildings such as the temple, synagogues, and teaching halls.

Then more direct evidence may be inferred from the references to what appears to be a dual structure which occur in Acts 2:46; 1 Corinthians 14:23 (Hendriks \& Kirstemaker 2002, 1 Cor 14:23); 1 Corinthians 16:19; and Colossians 4:15, 16 (Clowney 1987:2). Additional less direct evidence for this structure is found in Paul's letter to the Romans if a Corinthian origin is accepted. Paul includes a greeting from one Gaius (Rm 16:23). It appears that the small groups may have used the spacious home of this eminent citizen (Banks 1994:32) for a gathering together of the 'whole' church (Dunn 1998:541). For instance Murphy-O'Connor $(2004: 3,85)$ estimates that there were at least 50 believers in Corinth when Paul wrote to them in $53 \mathrm{AD}$ and they would have usually met in house church small subgroups.

There is good reason to suppose that what happened in those cities such as Jerusalem, Corinth, Laodicea, and those in Galatia reflects what happened in other cities of the Empire because of the restraints on the meeting places available to Christians. This limited them to meeting most often in homes. Although it is recorded that at Ephesus Paul was able to hire the 'lecture hall of Tyrannus' (Ac 19:9) even in this case Paul in his farewell address to the Ephesians elders, mentions teaching, 'publicly and from house to house' (Ac 20:20). So the house meeting was an important unit despite the availability of a lecture hall even in Ephesus.

\section{Evidence for small and large group meetings being considered as an 'ecclesolae in ecclesia' structure}

One implication of the 'ecclesiolae in ecclesia' concept is that the same communicative actions will be carried out in both the large and small groups, although the form of these actions take will differ because of the different dynamics between small and large groups. I have chosen five communicative actions to demonstrate this - proclamation, instruction, celebration, care, and service chosen from among the roughly similar lists given by Van der Ven (1996:81-83, 377-379), Meeks (1979:74), Heyns and Pieterse (1990:12-18, 59-61). What is important to note at this stage is that not only is there evidence of a dual structure, but also that the same communicative actions, except for that of service, occurred in both the small and whole church meetings. I call this 'actional equality'.

An actional analysis seems to reveal proclamation occurring both within small groups and to the multitudes in Acts 2, Acts 
5:42; 10:1-48; 11:14-15. Paul's commands in Philippians, Ephesians, and 1 Corinthians concerning proclamation are evidence that he expected the small and large gatherings to continue to actively proclaim the gospel after he had left the area. The use of small groups for instruction is recorded in Acts $2: 42,5: 42 ; 18: 7-11 ; 20: 7-12$, 20. Large group meetings for this purpose are recorded in the Temple in Jerusalem (Acts 2:42, 46), the synagogue (Acts 17:10), and hall of Tyrannus (Acts 19:9).

Two indisputable references to the action of celebration in small groups are found in Acts 2:42-47; 20:7-12. Further indirect evidence for this action in the small group meetings is suggested by Hadaway, DuBose and Wright's (1987:64) observation that the Lord's Supper grew out of the Passover feast that was first observed in the small group home setting. Heitink (1999:279) stresses the relational nature of these celebratory events when he suggests that these gatherings seem to have involved much interaction, personal contacts, affective relationships, common goals, and norms. The importance of this action in large groups ('the whole church') is stressed by Paul's corrective commands concerning it in 1 Corinthians 11:17-14:40.

Direct evidence of the action of care through the dual group structure is very limited in the Acts account. However, the overwhelming evidence for the central place of small groups in Christianity in the first century means that many references to the action of care in the epistles must have operated in this context (for example, Romans 15:1-3; Galatians 6:1-10; Philippians 2:1-4). Furthermore Van der Ven (1996:304, 305) suggests that the small group meeting provided a functional pastoral structure in the later apostolic, Pauline and postPauline communities. He equates the original small groups of Acts and the Pauline corpus with the oikos ${ }^{2}$ social formation, with its relatively low degree of overall organisation, which was easily transformed into a pastoral caring structure for the whole church as early Christianity developed.

There are no direct examples in Acts of the action of service resulting in small groups serving the needs of the world or of the whole church exercising an integrating function for the small groups. Indeed in Acts 6, the distribution of alms to widows was a function of the whole church. Yet despite this, the analysis does seem to support, on the whole, the concept that in some congregations, especially those founded by Paul, that a dual meeting structure existed, in which all the actions necessary for church life were found in both the small group and large group meetings, although in different ways.

\section{Supporting evidence of the ecclesiolae in ecclesia structure from conclusions of contemporary theologians}

Various New Testament scholars and researchers have interpreted the New Testament documents as indicating that

2.Filson (1939) was the first scholar to draw attention to the fundamental significance that the household institution (oikos) played in both the society of the Grecothat the household institution (oikos) played in both the society of the GrecoRoman world and the New Testament church. An oikos could mean 'all the member of the household, those who were under the authority of the head: wife, children and other blood relatives, as well as slaves and servants' (Moxnes 1997:21). It was the basis of economic activity, involving clients and business partners (Branick 1989:20) not only in the Greco- Roman world but also including the richer Greek influenced households in Palestine (Tidball 1984:79; Moxnes 1997:2). the dual structure was a fairly common model in the early church $^{3}$. Among these would be Osiek (2011:2) who states that the Pauline churches (with their dual structure) became 'nearly the norm'. Tidball (1984:89) deduces that there is clear biblical evidence of a multilevel assembling among the early Christians. Likewise, Doohan (1989:41ff.) concludes that because multilevel assembling was frequently practised in the Judaism out of which the early church emerged, and was commonly practised in the Hellenistic world of the day, it would be expected to be copied as a church meeting model. Heitink (1999:278ff.) agrees seeing an early dual structure consisting of small, intimate house church meetings and larger synagogue meetings.

More explicitly Branick (1989) writes:

The private dwelling functioned for the church on two levels. It formed the environment for house churches ... gatherings of Christians around one family in the home of that family ... On a second broader level, the private dwelling formed the environment for gatherings of the local church, the assembly of all Christian households and individuals in a city. (pp. 13,14)

Dunn (1998:541), whilst concurring with this interpretation modifies it by commenting on the differing frequency of large and small group meetings, 'Church gatherings consisted of more regular small house groups interspersed with less frequent (weekly, monthly?) gatherings of 'the whole church'.

That both small and large group meetings were considered to be 'church' is indicated by Clowney (1987:22-24) who interprets the New Testament evidence as demonstrating that the perception of 'church' and its assembling together was extremely flexible, being a multilevel concept. He cites various New Testament of meetings of different sizes being called 'church' in support of his contention. Pertinent to the dual model he states that, 'local churches come in surprisingly different sizes' and then mentions the situation at Laodicea. This comprised a 'central' local church congregation in the city along with a house church meeting in the house of Nympha as a seemingly common arrangement (Col 4:15) (Clowney 1987:23). In addition he mentions that the Westminster Divines saw this 'multilevel' assembling as indicating that smaller gatherings of the church could exist within larger gatherings of the church (Clowney 1987:23), although, admittedly, they used this to develop the 'Presbytery containing local congregations' structure. Yet their interpretation of the New Testament documents could equally well support the dual meeting idea of a large congregation containing small group meetings.

Although it is inconceivable that this was always a conscious idea in the early church or even applied all the time, it can be sufficiently deduced from the New Testament for Forsyth (1953:70) to comment. 'The Church in a private house was as much the church as the whole of Christianity in Corinth'. Dunn (1998:542) generalises on this inferring that for the apostle Paul every Christian assembly for worship was a meeting of the church, be it in a small group or of the whole church. (So for 3.For an alternate view see Trebelco (2013:34). 
instance when in 1 Timothy 3:15 he calls the church the household of God it shows that the household could be conceived of as the church in microcosm [Barclay 1997:77]). If this is the case then it is a key principle that will empower the dynamic of the dual structure in today's world and underlines this study.

Note must be taken that Rome may have been an exception to this common pattern of multilevel assembling. There is no suggestion that the Christians of Rome in the 1st century AD ever met as a whole in one place. A century later Justin Martyr mentions that this was still the case (Tidball 1984:83; Banks 1994:31, 32). Dunn (1998:542) suggests that the church in Rome thrived through a series of independent, largely unconnected house groups. The size of the metropolis and the diversity of its population suggest that the Roman model was exceptional. This would make it far more difficult to have a coordinated structure than in a much more homogenous and smaller city such as Laodicea and Corinth.

\section{Suggestions as to why the ecclesiolae in ecclesia structure may have been so effective in the early church \\ The sociological perspective}

From a sociological perspective a group may be defined as two or more individuals who are connected to one another by social relationships; engage in frequent interactions; identify with one another; are defined by others as a group; define themselves as a group; share beliefs, values, and norms about areas of common interest; and come together to work on common tasks and for agreed purposes (Forsyth 2006:2). A small group is most effective in the range of five to ten people (Vinogradov \& Yalom 1989:34; Van der Ven 1996:249). The upper limit for viability probably is in most cases from 12 to 15 people (Lawson 1993:6). Sociologists set the lower limit for an effective large group at 50 people (Coser et al. 1988:105).

There are major differences between the way small and large groups function. Effective small groups usually have most of the characteristics of primary groups, which are face-to-face association; a high level of commitment to the unspecialised character of that association; relative intimacy among participants; and informality (Dudley \& Hilgert 1987:34ff.). Whereas a large group tends towards greater formality and organisation; more distant relational ties; rules and norms; and needs a greater sense of purpose to encourage cohesion. The size of the large group formation does affect some aspects of group function (Rendle \& Mann 2003). However, once a congregation has reached the critical mass of 75 or so members, the differences between relatively small (75 members) and relatively large congregations (400 members) are unimportant (Pinto \& Crow 1982:304-316).

The sociological subdiscipline known as 'Group Theory' suggests why the dual group structure may have been so effective. Small and large groups complement each other's strengths and weaknesses in many ways so as to produce a powerful missional strategy. It has inherent sociological strengths and, despite the profound social and cultural differences (such as no oikos structure), significant similarities are emerging between the Roman world and today's world that suggest it may again be a very effective missional tool.

The strengths of a small group concerning proclamation are that, with the right encouragement and vision, members become more motivated to witness and reach out to the unchurched in their social networks (Nel et al. 2004:127ff.). It then provides a more effective environment in which to build the affective relationships required, with interested potential converts, to complete the process of conversion (Sanders 2002:624ff.). However, the size of a large group makes the potential combined size of the social networks of each member far greater and the likelihood of a greater cross section of society being reached because of the greater diversity of gifts, personalities, and social status within the group. They are also more able to attract attention and 'as increasing number of adherents adopt the novelty, there is a bandwagon effect characterized by more and more interest in and less resistance to the innovation' (Rambo 1989:95).

A combination of small group intimacy and large group resources exponentially increases the effectiveness of instruction. Research indicates a large majority of small group members perceived that their spiritual growth in understanding and discipleship has increased since they joined their small group because of the opportunity to ask questions, receive personal help, and model themselves on the more experienced in the group (Wuthnow 1994:221ff., $\mathrm{Nel}$ et al. 2004:12). However, large groups are more likely to include people with a range of skills (McCollum 2005:13) who are able to see and communicate the 'big picture' and teach knowledgably and with faithfulness to the doctrines of their particular faith tradition.

As concerns celebration, research indicates that almost all small group members perceive that their small group meets their needs for fellowship and community (Wuthnow 1994:4, Nel et al. 2004:130). The large group worship service is not the proper structure for experiencing such fellowship. Yet the large gathering is essential for community building and facilitating a sense of identity and purpose. It fosters an atmosphere of festival, celebration, and covenant renewal in a way that a smaller meeting cannot (Snyder 1975:105 ff.).

The action of care is perhaps the most important strength within a small group that a large group just cannot do effectively. Only a small group is able to satisfactorily meet the needs of people for the intimacy and trust that caring requires (George 1994:69). Research indicates that most small group members feel much more loved, cared for, and supported because they had joined a small group than when they just attended the large group meeting (Wuthnow's 1994:221ff., Nel et al. 2004:131). 
It is the perception of many in small satellite groups that being in the group encouraged them in the action of service by becoming more involved in their local congregation and in meeting the needs of their local community (Wuthnow 1994:322, Nel et al. 2004:131). However the main large church meeting to which they are attached possesses more resources than its attached small groups and is characterised by greater organisational differentiation and specialisation of function which enables it to serve the world by meeting a larger range of needs (Adamek \& Lavin 1975; Blau \& Schoenherr 1971).

\section{The missional paradigm of the early church}

As is well known, the paradigm concept is a perception theory which has entered theological discourse through the application of Kuhn's (1970) 'paradigm theory', found in his 'Structure of Scientific Revolutions'. Theologians such as Küng (1989) and Moltmann (1989) have applied this theory to theological discourse. It provides a broad understanding of what, often unconscious thought patterns and ideas, influences people's perception of reality, and thus what motivates their actions and thinking.

The theory may shed light upon the lack of missional fruitfulness that my research has revealed concerning contemporary congregations. I would suggest that it is primarily because the church members involved in the dual structures, although enthusiastic, were acting out of the motivations of the traditional 'Christendom' church paradigm, instead of a missional paradigm. I would therefore agree with Van Gelder and Zscheile (2011:163) that bringing a congregation into the missional paradigm depends more upon focusing upon renewing a congregation's identity through imparting missional theology than adopting the 'right' structures (see also Nel 2015:206).

The early church operated out of what has been designated the 'Apocalyptic' (Küng 1989:157) Paradigm. This is considered to have lasted from $30 \mathrm{AD}$ to $+/-313 \mathrm{AD}$. Much evidence suggests that the Apocalyptic Paradigm was missional. It was a time when many congregations were very strongly influenced by Paul's vision, as he expected them to be, as Bosch $(1991: 170,171)$ convincingly argues. The central reality of this paradigm was thus that the church as a local community was called out by God, in Christ, to engage in sacrificial witness to a hostile world (Shawchuck \& Heuser 1993:224). Bosch (1991:133ff.) analyses Paul's missional motivation, and thus that of the congregations he influenced through establishing them or through his letters, as stemming from a sense of concern; a sense of responsibility, and a sense of gratitude.

\section{According to Bosch (1991):}

The idea of an imminent judgment on those who do not obey the truth' (Romans 1:8) is a recurring theme in Paul. Precisely for this reason he allows himself no relaxation. His gospel is therefore'good news' for people who have wilfully sinned, who are without excuse, and who deserve God's judgment. (p. 134)

As a result, Paul is concerned to proclaim the good news of God's kindness, salvation, and imminent triumph.
This concern put him under an obligation to preach the gospel (Romans 1:14) because of his awareness of his debt to Christ in saving him, out of a desire to please and obey Him to whom he owed so much. I am not suggesting that the apostle Paul was a sociologist who studied group dynamics or that there was even an intentional use of this structure. Yet somehow the early church stumbled upon a church structure that was particularly effective in their social context.

Yet 'the deepest level of his missionary motivation' (1991:138) was Paul's overwhelming experience of the love of God in Christ. He was compelled by a continuous experience of Christ's love, which he passionately reciprocated. For Paul this love was a passion, obsession, and something he could not live without, making him 'almost insanely passionate' (2 Cor 5:14) for Jesus and his mission. This may be described as a truly missional vision. Empirical research ( $\mathrm{Nel}$ et al. 2004; Nel 2002) and the initial results of a small National Congregational Life Survey I helped conduct in eight UPCSA congregations in 2015 (yet to be reported) indicate that all three of these motivations seem to be lacking in many contemporary congregations. Thus, it is not surprising that the dual structure is not operating as missionally effectively as it potentially might.

\section{The social contexts in which the ecclesiolae in ecclesia structure flourished and then disappeared}

If we are going to be able to see whether or not such a dual group process may be a relevant structure for some congregations today it is necessary to look at the reasons for its development, perpetuation in Paul's ministry, and demise in the context of the first five centuries of the Christian era. Then we need to judge if there are similarities between that era and the present era that would justify any confidence concerning its effectiveness in today's world.

\section{The reasons for its emergence}

The first clearly and seemingly consciously reported dual group structure in the Acts record is that recorded in Acts 2:42-47. The question must be asked, 'What caused the seemingly sudden appearance of this structure?'

Jesus is recorded in the gospels as meeting with his disciples (sometimes with the women who served them) and the 70 in private houses, synagogues, with crowds, and in the Temple. These meetings seem to have been often informal and ad hoc, and others seem to have operated as permanent semistructured groups once they were initiated. Of these groups, the meeting of disciples may be considered a small group and the meetings with the 70 , in synagogues ${ }^{4}$, the crowds, and in the Temple may be considered as large group meetings.

4.It is very difficult to find evidence from the first century of the number people a synagogue accommodated when Jesus worshipped in them on the Sabbath Only six synagogue accommodated when Jesus worshipped in them on the Sabbath. Only six synagogues have been found in Israel which are generally accepted as dating between 50 B.C. and A.D. 100. Of these, that at Migdal has a meeting hall floor area of $120 \mathrm{~m}^{2}$ (Israel Ministry of Tourism 2009) and that at Gamla of $117 \mathrm{~m}^{2}$ (Levine 2000:51). This indicates that even despite the presence of interior pillars and furnishings they could easily accommodate large groups if one square metre is allowed for sitting space. Moreover, 'Jesus visits to these synagogues on the Sabbath were clearly timed to afford him maximum exposure to the population'. 
Meetings in private houses could either be small group or large group meetings, depending upon the size of the house.

Whether intentionally or not, it is very clear that Jesus used a multilevel meeting missional approach. Thus, it is possible that memories of his method of ministry either were permissive in this regard or were patterned by his disciples after Pentecost, either unconsciously or intentionally. It is arguable either way, but what is certain is that how he ministered influenced them greatly. Therefore, although during the life of Jesus there was no need for organisation, the evidence of the gospels suggests that he intentionally met with small and large groups. This would suggest that what he did in these groups might well have influenced how the apostles organised the church immediately after Pentecost.

In addition, like all human beings, the early church was influenced by social custom. There is now much sociohistorical evidence for a multilevel assembling in groups of various sizes being a traditional part of both Jewish and Greek culture. In Judaism there were many levels of meeting, identity, belonging, and gathering. These included the level of the Nation under God that assembled in the Temple, the synagogue which was a much smaller gathering, and meetings in private homes often in the extended family unit. These were seen as a vital part of the socio-religious structure of the community as evidenced in Deuteronomy 4:9-10, 11:19, the Passover (Ex 12:26-27) and the Sabbath (Heitink 1999:279).

In addition the urbanised Greek citizens living in Palestine, identified with the city (politeia), smaller voluntary associations that included guilds or religious groups (or koinonia), discipleship schools, and underpinning them all, the oikos; all of which Doohan (1989:47) believes considerably influenced the development of the early church.

The church was founded in a mostly hostile environment. The new movement faced spasmodic opposition by the religious authorities in Jerusalem. There was a developing hostility to Christian gatherings on the part of the synagogue or guilds as the first century passed the halfway mark (as in Ac 17:4-9; 18:4-8; 19:23-28) (Branick 1989:14) and especially after 64 AD when Nero's persecution began. The large group meeting would have given a sense of identity, administrative structure, organised service, opportunities for large group proclamation, skilled instruction, and provided the encouragement that the success of any new movement brings. But when it was unsafe to meet openly, the small group provided the necessary secrecy, continuing instruction (all be it at a less specialised level), and opportunity for some kind of celebration, community, and care that the members needed. The dual group structure would almost certainly provide continued flexibility for the early church in the face of hostility and persecution for the same reasons as for the first church in Jerusalem.

It also seems likely that Paul's (or the deutero Pauline) theological emphasis on the body of Christ and people of God metaphors may also have provided a doctrinal motivation for such a basic group process. The authors of the Pauline corpus use the image of the body to propose that diversity does not necessarily detract from unity and will promote mission, so long as interdependence is acknowledged (Meeks 1983:90). Thus they may well have considered it inconceivable that all the small groups in a city should not be united by meeting together in some way as 1 Corinthians 1:10-13 appears to demonstrate.

Finally it appears that because Christianity was a first generation religious movement Paul and others had tremendous freedom to innovate and create. Different concepts of the church seem to have been applied in different contexts (Schweizer 1961:23). Although they may have built upon traditions they were in a position to unrestrictedly try new ideas without much hierarchical interference, because of a weak unformed, authority structure to which members only voluntarily submitted (Bird 2002:242ff.). Thus, church organisation could flexibly allow form to follow function.

\section{The demise of the dual group process}

Evidence indicates that the dual group process disappeared sometime within a period dating from the end of the first century to midway through the fifth century, depending upon geographic location. The guiding premise must be that the early church's dual group structure ceased to function, at the latest, when small house churches disappeared. Obviously this still leaves a range of options open on the basis of archaeological and documentary evidence concerning the actual date of its demise, which is set out in the paragraph below.

Doohan (1989:143) believes that Paul stopped creating the small house church meeting towards the close of his ministry, which would be sometime after 60 AD, although those already in existence might have continued to operate long after his death. Krautheimer (1939:144-159), Branick (1989:14, 15), Esler (1997:137) and Küng (1996:152) consider that communities operated in functioning houses, to about 150 AD. Hadaway, DuBose and Wright (1987:45) would place the demise of the two-meeting structure within the Constantinian era, approximately 50-100 years later (see also, Blue 1994:120, 121).

If the dual group approach was the apostle Paul's preferred option and one of his missional strategies, and apparently very effective, why did it disappear?

Various theories exist. These are that: Paul may have insufficiently modelled the dual group structure to permanently affect church tradition; it was easier to combat heresy and schism with one large meeting, as opposed to many small groups (Branick 1987:168-170); when Constantine became Roman Emperor and persecution stopped a flexible, time-consuming structure was no longer needed; and finally the rise of the monastic movement in the fourth century (Chadwick 1991:496) may have diminished the pool of the most dedicated Christians who would have the commitment to become involved in more than one meeting a week. 
Perhaps, more importantly, the Constantinian religious settlement in the fourth country $\mathrm{AD}$, which recognised Christianity as the 'State' religion of the Roman Empire, changed Christianity's inner spirit from being a bottom up structure to a top down one. The pattern of 'one man, one building, and one territory' was extended throughout the whole Empire. This proved to be a very effective formula for the growth of the church throughout much of the age of the Christendom paradigm (Heitink 1999:94), which would still prove the case in many traditional cultures today, such as in traditionally European conservative cultures in South Africa.

The decline of the dual group process may also be attributed to the change in the social environment of the Western Roman Empire from the fourth century on. Christianity had entered a highly developed 'global' world with a complex, tightly organised society of interlocking political, social, economic, and religious structures, which was ethnically diverse (Meeks 1983:11, 13), composed of a bewildering array of races, languages, cultures, social groups, and religions (Dudley \& Hilgert 1987:9). In general there was religious pluralism and tolerance, punctuated with occasional severe local persecution (Smith 1971:74ff.). It was a society in which cities exercised political authority over its states, controlled the means of economic production, and were the drivers of trade, to support their often luxurious life style and comprised the educated elite (Esler 2000:11ff.). 'This matrix of ancient cultures and subcultures was the context in which early Christianity arose and prospered' (Osiek 2011:1).

Whilst in Republican Rome there must have been some who professed themselves to be deeply sceptical about the gods and their supposed activities (Beard, North \& Price 1998:42), this became more widespread in the early Empire. 'Lucian and Plutarch could each paint a picture of traditional religion in the doldrums' (Anderson 2001:162), which meant it could not withstand the dynamic opposition of Christianity. Finn (2000) adds to this picture of decaying belief in the old rituals and gods seeing it as a profound change in the sacred world of Graeco-Roman paganism because:

the close bonds between the human and divine worlds of the traditional religions had begun to unravel, leaving many with a longing for a secure and lasting intimacy with the divine. This provoked an identity crisis for many which, in turn, provoked a quest for a new and more secure sacred world. (p. 312)

The combination of Roman laissez-faire, urbanisation, globalisation, and dissatisfaction with traditional religions brought about a freedom, which had never existed before, that allowed people to choose new religions. This probably allowed the large group teaching combined with small group building of socialising relationships to be a powerful tool for evangelism.

By contrast, from the fourth century onwards, in the West, there was a decline of many urban centres (Wacher 1978:102, 103), with their accompanying oikos social construct. This may have been caused by the tax revenues previously accruing to cities now being channelled into State coffers to equip the military to face the Sasanian threat on the Eastern frontier in the mid third century (Heather 2006:115ff.). In addition, from the fifth century onwards, ethnic diversity was lost with the decline in mobility and the transport infrastructure and the regionalisation that accompanied the fragmentation of the Western Empire.

The dual group structure had developed in an urban religiously pluralistic environment where communication operates at two or more levels. The first level is that of mass expression reflecting the public sphere. The second is that of small group communication reflecting the primary groups (Hadaway, DuBose \& Wright 1987:61). It was now an anachronism and thus disappeared for 1500 years, to remerge only when when the social environment and theological presuppositions of the predominant religious paradigm changed for it be seen as necessary once more.

\section{Why the dual structure might be fruitful in today's world}

Today's world shows some interesting contextual similarities to the Greco-Roman world. Goodman (2008:168) comments, 'the contemporary world (is) ... more similar to the multicultural society of the pagan Roman Empire than to any intervening period ...', albeit, today, on a much larger scale. (For instance there were only 22 Mediterranean cities with a population of larger than 40000 people, of which Rome was by far the largest with a population of between 650000 and 700000 [Finn 2000:296]). The similarities that are pertinent to my argument include the ethnic, racial, linguistic, social, and religious diversity; the freedom to experiment with religious structures and ideas; widespread religious cynicism; and the freedom to choose which faith or 'unfaith' to follow. All these existed, mostly although not only, in the urban areas of the Roman Empire.

The 'ecclesiolae in ecclesia' structure, as we have seen above, flourished in urban areas, where the citizens would find it easy to attend two meetings, as well as the coordination of meetings being relatively simple to manage. Immense urban centres of ever growing size are now increasingly dominating today's world (Van der Ven 1996:234). South Africa has not escaped this trend. It is now one of the most urbanised countries in Africa, where nearly $62 \%$ of its population of 50 million live in cities (Turok 2012:3). It is suggested that this urbanisation will favour the regular attendance at two weekly or biweekly meetings and the coordination required for the 'ecclesiolae in ecclesia' structure to flourish. In fact, this overwhelming urbanisation would indicate that this structure will be even more productive in the modern era than in the Roman Empire.

The structure, when combined with the apostolic paradigm of church, was very missionally effective, as we have seen above, in the religiously pluralistic, multi-ethnic, linguistically diverse urban areas. One reason for this was that it enabled the church to reach and cater for this diversity in a variety of ethnically and linguistically differentiated small groups and 
then integrate the small group members through the large meeting into the church, which is the implication of the sociological group theory considered above.

In addition, the dual structure should be able to more effectively penetrate society than just a church with a large congregational meeting, because it is more flexible (Snyder 1975:144; Gibbs 1981:242). It requires no great resources, other than the time their members devote to them each week. It is easy to start and disband compared to the congregational structure (Snyder 1975:140; Wuthnow 1994:23). It may be established to target specific cultural, interest, social, and ethnic groups that will not feel at home in the congregation until a significant number are involved as worshippers. Moreover the meeting's location, time, frequency, and duration can be very easily adapted to the needs of its members (Gibbs 1981:242).

The structure also enables mission to be more effective in a society in which religious cynicism, doubt, and even opposition to most religions is prevalent, as it was in the early Roman Empire. This stemmed from secularisation of society. It was a form of secularism in which many of the educated elite outwardly kept religious rituals but inwardly doubted or even despised them and did not allow them to guide their morality (Esler 2000:15; Finn 2000:312). Secularisation is the desacralisation and demystification of society's worldview as is happening among many educated people in today's world, (Küng 1996:763; Van der Ven 1996:153, 231; Heitink 1999:44), including South Africa. This results in a 'decrease of religious activities and convictions ... (and) a restriction of the scope of religion' (Heitink 1999:43). One cannot be certain, but human nature being what it is, it would be surprising if the small groups were also not a place where seekers could ask their diverse questions and get individualised answers that were tailored to their needs, as may happen in today's small groups. It provides an opportunity for Christians to air their doubts and share their opinions. Questions arising from the pulpit messages and coming out of life's experiences can be dealt with on a personal basis (Gibbs 1981:244, 245).

Another factor is that pluralism has resulted in a loss of confidence among many believers concerning the authority and uniqueness of the Christian revelation. And as in the Greco-Roman world believers are facing an increasingly hostile religious or spiritual environment because Christianity is competing with many other ideas, either secular or religious (Hunt, Hamilton \& Walter 1997:3), then the superior strengths of the basic group process allied with the ecclesiolae in ecclesia concept in the actions of instruction and care could well be exploited to instruct and encourage Christians.

The emergence of faith communities influenced by the metaphors of the church as the Body of Christ and the People of God since Vatican II emphasised its rediscovery, indicates that the church is once more developing a theology that can support and encourage the introduction of the dual group process. These metaphors emphasise diversity within unity and the mobilisation of the laity with the result that this structure will be seen as an advantage and almost as a natural corollary of such an ecclesiology.

Finally the modern world, as did the early Christian world, provides the freedom to experiment with a dual group structure. In its first few years believers appear to have experienced a remarkable freedom to experiment with new structures in order to contextualise their evangelism and continuing discipleship, before order was imposed from above in the second century onwards. This freedom to experiment is once more becoming increasingly evident as hierarchical ecclesiological institutional structures are breaking down in today's world.

The above indicates that the dual group structure could be a very relevant key in a missional strategy. But if it is to be exploited to the full, then the small group's component should no longer be perceived as no more than just 'pastoral care' add-on. Instead it should be perceived as an ecclesiolae, in which the full range of communicative actions (proclamation, instruction, celebration, care, and service) is expected to operate. Only then will the full potential of the basic group process along with the ecclesiolae in ecclesia concept be fully realised and the way opened for many more local congregations to investigate and fully experiment with what some early churches did so well!

\section{Recommendations}

What might we learn from this? I believe it is that the basic components that we need to determine before we can implement a missionally fruitful basic group process concern three aspects: congregational missional motivation, social context, and actional analysis.

It is clear that unless a congregation is on the way to becoming missional and establishing a predominant missional consensus among its worshippers that establishing a dual group structure will not make it missionally fruitful. There needs to be an impelling spiritual motivation originating from an experience of God's grace and love through worship, the word, in the power of the Spirit for this to be the case. As Dulles (1987) and Snyder (1991) indicate this comes much more easily to some congregations than others, predicated upon the prevailing church or kingdom model that is embedded in the congregation's DNA. Thus it would be helpful if the leaders would read these books to discover what models are influential in their congregations and what they may have to learn, pray, do, and teach in order to establish a missional paradigm. I also recommend $\mathrm{Nel}^{\prime} \mathrm{s}$ (2015) latest book which provides ideas concerning 'the ministry of cultivating missional churches' (Nel 2015:12).

I suggest, that in addition, the social context of the congregation be analysed. Hendriks (2004:69-103) and Nel (2009:13; 2015:273ff.) both stress the importance of analysing the social context of a congregation demographically, geographically (social location), and culturally, before implementing any 
church program. For instance, traditional rural communities may not be very receptive to the ecclesiolae in ecclesia type of missional approach. Thus it is recommended that congregations research the degrees of secularisation, urbanisation, and predominant epistemological paradigms (traditional, modern, or postmodern) in their neighbourhoods to determine whether it contains factors that will indicate whether or not the dual group structure will give the church an appropriate and therefore more effective missional strategy.

It is recommended that along with the above, an actional analysis, (as set out in this article) using the communicative actions of proclamation, instruction, celebration, care, and service is suggested. This will involve examining what happens and who is using their gifts effectively in performing these actions in the 'whole' church meeting and the small satellite groups. This may result in changes being necessitated in what happens in both size of meetings, a reassignment of personnel from one to the other depending upon their gifts, and the establishment of clearer objectives for each size of meeting.

Finally, we need to accept that we can do nothing except by God's grace. In an exegesis of Psalm 127, Möller (1987:222ff.) comments that there are three things that we cannot do without God's help: To build a house; keep watch over a city; or provide for our needs. Jesus' words in John 15:5 (New International Version [NIV]) may be a commentary on this psalm: 'For apart from me you can do nothing', which could be appropriately applied to building up a congregation!

\section{Conclusion}

In South Africa, 'Nearly two-thirds (62 per cent) of its total population of 50 million live in urban areas' (Turok 2012:3). This, along with all the other contextual factors mentioned above, suggests that the dual structure which worked so well in the early church in urban areas will be very effective in the urban areas of our country today, if congregations rely upon the grace of God and passionately embrace their missional and relational identity in the triune God.

\section{Acknowledgements Competing interests}

The author declares that he has no financial or personal relationships which may have inappropriately influenced him in writing this article.

\section{References}

Adamek, R. \& Lavin, B., 1975, 'Interorganizational exchange', in A. Negandi (ed.), Interorganizational theory, pp. 196-209, The Kent State University Press, Kent, OH.

Anderson, G., 2001, 'Greek religion in the Roman Empire', in D. Cohn-Sherbok \& M. Coutt (eds.), Religious diversity in the Graeco-Roman World, pp. 143-163, M. Coutt (eds.), Religious diversity in the
Sheffield Academic Press, Sheffield, England.

Banks, R., 1994, Paul's idea of community, Hendrickson Publishers, Massachusetts.

Barth, K., 1956, Church dogmatics, The Doctrine of Reconciliation, Vol. 4.1, T \& T Clark, Edinburgh.

Barclay, J., 1997, 'The family as the bearer of religion', in H. Moxnes (ed.), Constructing early Christian families, pp. 66-80, Routledge, London.
Beard, M., North, J. \& Price, S., 1998, Religions of Rome, A History, Vol. 1, Cambridge University Press, Cambridge, England.

Bird, F., 2002, 'Early Christianity as an unorganized ecumencial religious movement', in A Blasi, J. Duhaime \& P. Turcotte, (eds.), Handbook of early Christianity, pp. 225-246, AltaMira Press, Oxford.

Blau, R. \& Schoenherr, A., 1971, The structure of organizations, Free Press, New York.

Blue, B., 1994, 'Acts and the house church', in D. Gill \& C. Gempf (eds.), The book of acts in its first century setting, pp. 119-222, William B. Eerdmans Publishing Company, Grand Rapids, MI.

Bosch, D., 1991, Transforming mission, Orbis Books, New York.

Branick, V., 1989, The house church in the writings of Paul, Michael Glazier, Wilmington, DE.

Calvin, J., 1970, Institutes IV, MacDonald Publishing Company, Florida.

Chadwick, H., 1991, 'Envoi: On taking leave of antiquity', in J. Boardman, J. Griffin \& O. Murray (eds.), The Oxford history of the Roman world, pp. 449-477, Oxford University Press, Oxford.

Clowney E., 1988, Presbyterianism, in S. Fergusen, D. Wright \& J. Packer (eds.), New Dictionary of Theology, Inter-Varsity Press, Leicester.

Coser, L., Nock, S., Steffan, P. \& Rhea, B., 1988, Introduction to sociology, Harcourt Brace Jovanovich Publishers, London.

Dreyer, W.A., 2012, 'The amazing growth of the early church', HTS Teologiese Studies/ Theological Studies 68(1), Art. \#1268, 7 pages. http://dx.doi.org/10.4102/hts. v68i1.1268

Doohan, H., 1989, Paul's Vision of the Church., Michael Glazier Inc., Delaware.

Dudley, C. \& Hilgert, C., 1987, New Testament tensions and the contemporary church, Fortress Press, Philadelphia, PA.

Dulles, A., 1987, Models of the church, Doubleday, New York.

Dunn, J., 1998, The theology of Paul the apostle, William B. Eerdmans Publishing Company, Grand Rapids, MI.

Esler, P., 1997, 'Imagery and identity in Gal. 5.13 to 6.10', in H. Moxnes (ed.), Constructing early Christian families, pp. 121-149, Routledge, London.

Esler, P., 2000, 'The Mediterranean context of early Christianity', in P. Esler (ed.), The early Christian world, Vol 1, pp. 3-25, Routledge, London.

Filson, F., 1939, 'The significance of the early house churches', Journal of Biblical Literature, 58(2), $105-106$

Finn, T., 2000, 'Mission and expansion', in P. Esler (ed.), The early Christian world, Vol. 1, pp. 295-315, Routledge, London

Forsyth, D., 2006, Group dynamics 4e [international student edition], Thomson Wadsworth Publishing, Belmont, CA.

Forsyth, P., 1953, The church and the sacraments, Independent Press, London.

George, C., 1994, The coming church revolution, Fleming H. Revell, Grand Rapids, MI. Gibbs, E., 1981, I believe in church growth, Hodder and Stoughton, London.

Goodman, M., 2008, Rome and Jerusalem, the clash of ancient civilizations, Penguin Books, London.

Hadaway, C., DuBose, F. \& Wright, S., 1987, Home cell groups and house churches, Broadman Press, Nashville, TN.

Heather, P., 2006, The fall of the Roman Empire, A New History, Pan Books, London.

Heitink, G., 1999, 'Practical theology', Wm. B. Eerdmans Publishing Co., (translation of Praktische Theologie, Kok-Kampen, 1993), Grand Rapids, MI.

Hendriks, H.J, 2004, Studying congregations in Africa, Lux Verbi BM., Wellington.

Hendriks, W. \& Kirstemaker, S., 2002, Baker's New Testament commentary, e-sword edition, Baker Academic, Grand Rapids, Michigan.

Heyns, L. \& Pieterse, H., 1990, A primer in practical theology, Gnosis, Pretoria.

Hunt, S., Hamilton, M. \& Walter, T., 1997, Charismatic Christianity - Sociological perspectives, MacMillan Press, Basingstoke.

Israel Ministry of Tourism, Sept 14 2009, 'Unique ancient synagogue exposed at Sea of Galilee'.

Krautheimer, R., 1939, 'The beginning of Christian architecture', Review of Religion, 4 127-48.

Kuhn, T., 1970, The structure of scientific revolutions, University of Chicago Press, Chicago, IL.

Küng, H., 1989, 'Paradigm change in theology: A proposal for discussion', in Tracey and Küng (eds.), Paradigm change in theology, T. \& T. Clark, Edinburgh.

Küng, H., 1996, Christianity, essence, history and future, Continuum, New York.

Lawson, J., 1993, 'The utilization of home cell groups in leadership development and local church ministry', Christian Education Journal, 13, 67-73.

Levine, L., 2000, The ancient synagogue, the first thousand years, Yale University Press, New Haven, CT.

McCollum, M., 2005, 'Congregation size: What the research tells us', Congregations Magazine, pp. 13-17, Alban Institute, New York, Winter 13,

Meeks, M., 1979, 'Moltmann's contribution to practical theology', in T. Runyan (ed.), Hope for the church, pp. 57-74, Abingdon Press, Nashville, TN.

Meeks, M., 1983, The first urban Christians, Yale University Press, New Haven, CT.

Möller, C., 1987, Lehre vom Gemeindeaufbau, Band 1, Vandenhoeck \& Ruprecht, Göttingen. 
Moltmann, J., 1978, The open church, SCM Press, London.

Moltmann, J., 1989, 'Paper delivered at paradigm symposium at Tübingen', in D. Tracy and H. Küng (ed.), Paradigm change in Theology, T. \& T. Clark, Edinburgh.

Moxnes, H., 1997, Constructing early Christian families, Routledge, London.

Murphy-O'Connor, J., 2004, 'Paul: His Story', Oxford University Press, Oxford.

Nel, M., 2002, 'Missionêre koers van 58 gemeentes in Suid-Afrika - 'n empiriese verslag', Praktiese Teologie in Suid-Afrika 17(1), 53-75.

Nel, M., Tucker, A. \& Smit, C., 2004, 'An investigation of the development of the cell church concept in the Western Cape', Practical theology in South Africa, 19/1, 119-135.

Nel, M., 2009, 'Congregational analysis: A theological and ministerial approach', HTS Teologiese Studies/Theological Studies 65(1), 432-448.

Nel, M., 2015, Identity-driven churches, Biblecor, Wellington, SA

O'Brien, P., 1987, 'The church as a heavenly and eschatological entity', in D. Carson (ed.), The Church in the Bible and the world, pp. 88-119, 307-311, The Paternoster Press, Exeter.

Olson, D., 1989, 'Church Friendships: Boon or Barrier to Church Growth?' Journal for the Scientific Study of Religion, 28 (4), 432-447.

Osiek, C. \& Balch, D., 1997, Families in the New Testament world, Westminster John Knox Press, Louisville, KY.

Osiek, C., 2011, 'How much do we really know about the lives of early Christ followers?', HTS Teologiese Studies/Theological Studies 67(1), Art. \#841, 5 pages. http://dx.doi.org/10.4102/hts.v67i1.841

Pinto, L. \& Crow, L., 1982, 'The effects of size on other structural attributes of congregations within the same denomination', Journal for the Scientific Study of Religion, 21(4), 304-316.

Rambo, L., 1989, 'Conversion: Toward a holistic model of religious change', Pastoral Psychology 38, 47-63.

Rendle, G. \& Mann, A., 2003, Holy conversations: Strategic planning as a spiritual practice for congregations, Alban Institute, New York.

Sanders, J., 2002, 'Conversion in early Christianity', in A. Blasi, J. Duhaime \& P. Turcotte (eds.), Handbook of early Christianity, pp. 619-642, AltaMira Press, Oxford.
Schweizer, E., 1961, Church order in the New Testament, SCM Press, London.

Shawchuck, N., \& Heuser, R., 1993, Leading the Congregation, Abingdon Press, Nashville.

Smith, M., 1971, From Christ to Constantine, Inter-Varsity Press, London.

Snyder, H., 1975, New wineskins, Marshall Pickering, Basingstoke.

Snyder, H., 1991, Models of the kingdom, Abingdon, Nashville, TN.

Tidball, D., 1984, The social context of the New Testament, Zondervan Publishing, Grand Rapids, MI.

Trebilco, P., 2013, 'Early Christian communities in the Greco Roman city: Perspectives on urban ministry from the New Testament', EX AUDITU 29, 25-48.

Tucker, A.R., 2003, 'An investigation of the development of the cell church concept in the western cape', Dissertation, Faculty of Theology, University of Pretoria.

Turok, I., 2012, Urbanisation and development in South Africa: Economic imperatives, spatial distortions and strategic responses, International Institute for Economics and Development, London.

Van der Ven, J., 1996, Ecclesiology in context, William B. Eerdmans Publishing Company, Grand Rapids, MI.

Van Gelder, C. \& Zscheile, D., 2011, The missional church in perspective, Baker Publishing Group, Grand Rapids, MI.

Vinogradov, S. \& Yalom, I., 1989, Group psychotherapy, American Psychiatric Press, Arlington, TX.

Wacher, J., 1978, Roman Britain, J.M. Dent \& Sons, London.

Volf, M., 1998, After our likeness, the church in the image of the trinity, William B. Eerdmans Publishing Company, Grand Rapids, MI.

Volf, M. \& Welker, M., 2006, God's life in the trinity, Fortress Press, Minneapolis, MN.

Walker, J., 2014, Testing fresh expressions, identity and transformation, Ashgate Publishing, Farnham, England.

Welker, M., 1994, God the spirit, Fortress Press, Minneapolis, MN.

Wuthnow, R., 1994, Sharing the journey, The Free Press, New York.

Young, D., 1989, New life for your church, Baker Book House, Grand Rapids, MI. 